\title{
The sacred and the secular: the life and death of Terri Schiavo
}

I urge all those who honor Terri Schiavo to continue to work to build a culture of life, where all Americans are welcomed and valued and protected, especially those who live at the mercy of others. The essence of civilization is that the strong have a duty to protect the weak. - US President George W. Bush, Mar. 31, 2005

[I]deological thinking is a direct and explicit challenge to political thinking. - Bernard Crick, In Defense of Politics, 5th rev, 2000

I $\mathrm{n}$ the last weeks of Terri Schiavo's life, strangers around the world became familiar with photographs and video clips of this profoundly incapacitated woman smiling in what her parents interpreted as recognition and her physicians as a subcortical reflex. In medical and legal opinion, Terri Schiavo's cognizance of her self and her life ended in 1990, when she suffered a cardiac arrhythmia and massive cerebral cortical encephalopathy that left her in a persistent vegetative state. Her facial expressions, along with a seemingly "normal" sleep-wake cycle, constituted but one dimension of the cruelty of this condition.

The personal tragedies of end-of-life decisions normally pass unnoticed beyond the afflicted circle of family and friends. In 1976 the case of Karen Ann Quinlan established in the United States the principle that families may take precedence over the state in end-of-life decisions; after a long and public battle, Quinlan's parents were allowed to unplug the respirator that maintained this comatose young woman in a merciless semblance of life. Despite multiple appeals to the courts, the Schiavo case has created no major legal precedents in the US, but Schiavo's very public death may well set in motion legislative changes to satisfy those social conservatives who would like to translate all knotty questions into the rhetoric of a "culture of life."

The trouble with slogans of any stripe is that they obfuscate complex questions that need to be examined clearly. Thus the "culture of life" catchphrase serves to cloud important distinctions between a range of ethical questions, from end-of-life decisions, including assisted suicide, to stem-cell research, cloning and access to abortion. More than one commentator has viewed the "rightto-life" fight to prolong Schiavo's pitiable existence as an anti-abortion campaign "by other means." Even the President of the United States has used her case as a stalkinghorse for his government's agenda, couching his condolences to the Schiavo "families" in the same sort of language he has used to describe the "War on Terror." This same government is eager to tackle other metaphysi- cal matters through legislation on stem-cell research and abortion, and has also been accused of stacking national scientific advisory committees on the basis of the religious and moral views of scientists. ${ }^{1}$

Few of us could honestly say that we would prefer governments and courts never to weigh in on questions concerning the sanctity and dignity of life, never to exert a protective influence in these matters. But there seems little doubt that, in North America, ideology and religion have begun to seriously distort the type of consensus-building that is the proper business of democratic politics.

Where do physicians find themselves in such debates? Medicine is a secular and scientific profession that, for all that, must still contend with the sacred matters of birth, life and death. In practice, physicians must set aside their own beliefs in deference to the moral autonomy of each patient - or else transfer that patient's care to someone who can meet this secular ethic. If the Schiavo case teaches nothing else, it is the pragmatic lesson that physicians do well to encourage patients to discuss end-of-life preferences with their families and loved ones long in advance of what they might imagine to be their appointed hour. And, in helping families face that end, whenever it comes, the CMA Code of Ethics states that physicians should "ascertain wherever possible [their] patient's wishes about the initiation, continuation or cessation of life-sustaining treatment." In this issue, Glenys Godlovitch and colleagues describe a littleknown case in which an Alberta court helped a family to make, peaceably, such a determination (page 1172), ${ }^{2}$ and a commentary by Charles Weijer reflects on the physician's role in helping families to remain intact under the pressure of end-of-life decisions (page 1197). ${ }^{3}$

The emotionalism and rancour that swirled around the Schiavo case underscores a wider societal duty borne by the medical and scientific community. This is to remain alert to political and legislative tendencies that impose imprecise moral generalizations on the majority, at the expense of reason, scientific understanding and, not infrequently, compassion. - CMAJ

\section{References}

1. Union of Concerned Scientists. Scientific integrity in policy making. Available: www2.ucsusa.org/global_environment/rsi/page.cfm?pageID=1322 (accessed 2005 Apr 4).

2. Godlovitch G, Mitchell I, Doig CJ. Discontinuing life support in comatose patients: an example from Canadian case law. CMA7 2005;172(9):1172-3.

3. Weijer C. A death in the family: reflections on the Terri Schiavo case [editorial]. CMA7 2005;172(9):1197-8 